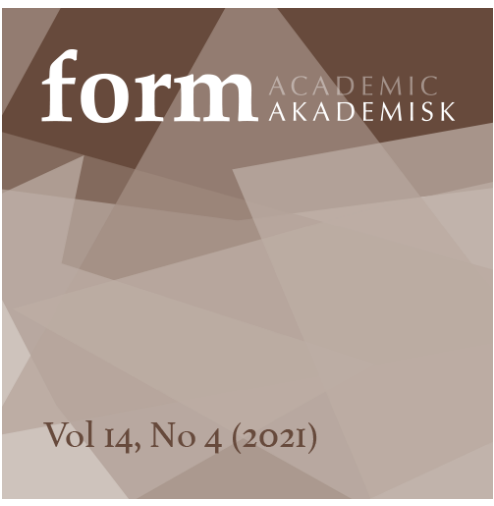

Tore Andre Ringvold

Assistant Professor

Oslo Metropolitan University, Norway

tore.andre@gmail.com

Liv Merete Nielsen

Professor (PhD)

Oslo Metropolitan University, Norway

livmn@oslomet.no

\title{
Complexity, interdisciplinarity and design literacy ${ }^{1}$
}

\begin{abstract}
In today's complex world, a variety of perspectives are needed to better understand and solve challenges. For decades, global organisations and researchers have pointed to interdisciplinarity as a way forward for educational systems. Educational research offers great possibilities and gains for students involved in interdisciplinary teaching and learning processes, and the interdisciplinary nature of design thinking and practice can play a vital role in interdisciplinary general education. This paper explores how future scenario-building, as part of general design education, can serve as a framework for inter-disciplinarity in general education and contribute to a better understanding of complex problems, challenges and design literacy.
\end{abstract}

Keywords:

Interdisciplinarity, general design education, future scenarios, design literacy, design thinking

\section{INTRODUCTION}

With the world and societies changing rapidly, educational systems are challenged to make future citizens capable of solving increasingly complex problems and to teach them to create new opportuneities for themselves and fellow citizens. The tasks ahead are enormous. Battling climate change, unemployment, possible social unrest and other geopolitical challenges demands an ability to understand today's world and the capability to create and innovate solutions.

Design education at both a general educational level and a tertiary level can play an important role in the development of learning necessary for sustainable societal development. We ask how interdisciplinarity in learning processes can contribute to seeing the broader picture and give students a deeper understanding of different phenomena. This paper discusses how the interdisciplinarity of future scenario-building school projects in general design education might contribute to such deeper understanding. 


\section{BACKGROUND}

\section{The demand for interdisciplinarity}

In the 20th century, education in Europe developed and transformed from a strictly divided disciplinary school system far removed from how individual selves experience the world and its complexity towards a learning ideal promoting a more holistic interdisciplinary explorative approach. In a report on interdisciplinarity, UNESCO stated:

From an educational point of view, teaching that is divided into separate disciplines runs counter to the pupil's natural approach to the exploration of his environment, and consequently it provides less incentive for the pupil unless he takes a particular interest in this or that subject. (UNESCO, 1986, p. 16)

While multidisciplinarity is characterized by its sequential, juxtaposed and coordinated nature, interdisciplinarity (ID) is characterized by integrating, interacting, linking, focusing and blending (Klein, 2010). Most schools in the Western world teach multidisciplinary through subjects taught throughout the day in a sequential fashion and, '... when intentionally aligned, in a Coordinating mode' (Burns, 1999; Klein, 2010). A variety of educational research shows that ID teaching increases student learning '...including gains in the ability to recognize bias, think critically, tolerate ambiguity and acknowledge and appreciate ethical concerns' (Science Education Resource Centre, 2017).

Ronald Barnett (2012) argued that there is a need for a pedagogy that focuses on learning not in terms of skills or even generic skills, but in terms of human qualities and dispositions. Learning for an unknown future demands an ontological shift in education, as today's pedagogy does not address the 'supercomplexity' of reality (Barnett, 2012).

In a reality consisting of youth alienation, school drop outs, increasing polarisation and societal fragmentation, there is a need for a more integrated human focus on learning. The way general education in Europe has traditionally been organised does not achieve the ideal of interdisciplinarity. Phenomena descriptions and problem-solving within the framework of isolated school subjects does not necessarily yield the perspectives needed for a deeper understanding. Learning should be increasingly organised and facilitated in a manner that fits the complex reality of today and tomorrow.

\section{The interdisciplinarity of design}

The activity of design in the understanding of design as problem-solving can be interdisciplinary or transdisciplinary.

\footnotetext{
In order for the designed artefact to be truly valuable to all those who interact with it, designers have to consider issues of aesthetics, usability, ergonomics, safety, marketability, manufacturability, functionality and sustainability. This requires a wide range of skills and knowledge. Design has therefore been described as science and art, as communication and argumentation, and as thinking and inventing. (Boradkar, 2010, p. 273)
}

The interdisciplinary nature of design and design thinking (Darbellay, Moody, \& Lubart, 2017) allows us to see general design education as a framework for interdisciplinarity in general education. This is a possible argument for expanding general design education to achieve greater potential for learning outcomes and curricular activity.

\section{Future scenarios, design activism, speculative design and critical design}

Within the context of design, the term 'future scenario-building' can be understood as a working method that describes a possible future and provides fertile grounds for innovative and challenging design processes. In the professional design context, the goal is not the scenario itself, but, rather, the design process that follows (Willis, 2005). Scenarios are often narratives, and they follow certain approaches or forms. Future scenarios can help designers to avoid excessively favouring the present (Thorpe, 2007). Through scenarios, designers can free themselves from the idea of what a product is. Thus, scenarios are an important tool in creating a better relation between products and user needs 
(Willis, 2005). If designers focus more on user needs and detach themselves from existing technologies, they might create possible solutions that are more closely linked to these needs. A specific example is a car: A person does not necessarily need a steel structure with an internal combustion engine and four wheels; rather, he/she needs a method to get from A to B.

Scenarios and design also have common qualities. They are both future-directed and represent attempts at prefiguration (Willis, 2005). Following Willis (2005), we see future scenarios as prefigurative thought exercises that are similar to design: having an idea about how something should be and actualising it. Through exercises and tools like future scenarios, students can practice pre-figurative thinking and actualising design. In a teaching situation in which students get to work with future scenario-building, opportunities to see products in a larger context might facilitate a greater understanding of such topics as consumption and environmental impact. Liv Merete Nielsen stated that visualizing ideas and solutions not yet articulated presupposes a competence to visualize these ideas; that is, it does not happen naturally and needs to be trained or developed (Nielsen, 2013). We believe that a good arena for this is the general educational school system, in which citizens can work with a common set of teaching goals.

The concept of design is usually and traditionally thought of as giving form to an object or product for aesthetic and functional purposes. However, the concept of design has changed and is changing. Design is increasingly seen as beneficial to many other aspects of human life: For example, it can promote sustainability through material and manufacturing choices, how designers think and the framework of processes in which they work (Cross, 2011). Fuad-Luke (2009) saw the role of designers as one of an opportunity to change society, and he stated that design can be used as a tool for activism. He described this design activism as creating a counter-narrative that seeks to create and balance positive social, institutional, environmental and economic change, which can be created through fantasy, practice and a design way of thinking. According to Fuad-Luke (2009), design activism can also create a change in the activist him/herself. In this understanding of what design knowledge can be, we see design as an opportunity to actively change society for the better, either through fantasy, design practice or design thinking.

Design can be an opportunity to speculate about how things could be and to try out possible futures to create a ground for discussion and reflection about current society (Dunne \& Raby, 2013). Possible futures created should not necessarily be positive ones, as a positive future might not provide the best material for discussion or reflection about today (Dunne \& Raby, 2013). A focus on more negative and darker futures might spark more useful reactions, thoughts and reflections about what we see as negative developments in today's society. Scenarios also provide an opportunity to critique and use design to challenge existing paradigms. Matt Malpass (2017) saw design research as having the ability to provoke discussion about an object and to engage a public as an instrumental application. We further see this possibility in future scenario-building and design as a framework in education for insight, reflection and critique.

In this study, we ask: How can the interdisciplinarity of future scenarios in general design education contribute to understanding the complexity of phenomena? Furthermore, we aim to discuss how the interdisciplinarity of future scenarios in a general design education can play a role in students' reflection and critical thinking.

\section{RESEARCH METHOD}

\section{Action research}

The research method used in this study was action research. Action research is a method to improve practice and produce evidence on how such practice can be improved (McNiff, 2013). Through the collection of empirical data, analysis and discussion, we wanted to explore and produce documentation of how scenario-building can contribute to the possible content and development of general design education. The data gathered through the study included participatory observation notes/photos/ audiotapes, qualitative research interviews and the students' scenario work. We see the informants as social actors who interact with society on different levels. In this understanding, we saw the scenarios 
as narrative expressions that, together with interviews, could provide valuable information about students' attitudes regarding their work on the school project.

During the two-week period that the school project lasted, the teacher-researcher (Ringvold) acted together with the students' ordinary teachers. Ringvold had experience and a background in teaching and as a design professional. He did not have any prior knowledge of, or connection to the school or any of the students or teachers involved in the project. To gather data from observation, the classes were audiotaped, and notes and photographs were taken. Student work was photographed, and interviews were audiotaped and transcribed. The student interviews were organised in several focus groups, each consisting of three students. Ethical regulations of individual and parental consent were followed.

The school project 'Build Your Own Future' was conducted with a 7th grade class (age: 12 years) in the fall of 2013 in Norway. The development of the school project was based on an understanding of future scenario-building as a four-phase process (Ringvold, 2014):

1. Finding a focus area.

2. Identifying and describing driving forces.

3. Developing the scenario.

4. Presenting the scenario

Over the course of two weeks, after choosing between transportation or health and nutrition as a focus area, the students worked on six main tasks. The work resulted in written and visual descriptions of society in the year 2043. The six tasks consisted of:

1. Interviewing an elder. During the interview, both the student and the interviewed elder completed a survey about society today and in the past. The survey covered such areas as technology, health, energy and consumer patterns.

2. Information gathering/context research.

3. Developing a future scenario and creating scenario descriptions.

4. Making a collage presentation of the future scenario containing the written scenario descriptions.

5. Developing design specifications.

6. Drawing and presenting a product design.

The scenario was the setting for future products designed by the students. The school project mainly took place during the students' art and design classes, but the project was interdisciplinary in its approach and framework, as it included an opportunity to work with competences in science and mother tongue classes through the scenario-building activity. This eased the planning of the project by allowing more time for the project. In the work with the scenario-building, the students researched and identified changes and developments within the fields of energy, technology, transport, environment, health and nutrition. The students' work and research interviews formed the empirical basis for the study. The interpretation of the empirical material revealed several types of learning and insights that could contribute to the discussion on the outcome of this study.

\section{DISCUSSION}

\section{Seeing and understanding complexity}

In today's rapidly changing world, in which reality is described as 'supercomplexity' (Barnett, 2012), general education should help students understand the complex nature of our surroundings. This can be done by identifying what changes are happening, why they are happening and what their consequences may be. In this educational change to better see and understand the complex nature of our world, we see interdisciplinarity as an approach that can help students comprehend the interdisciplinarity of the world itself. 


\section{A variety of future stories}

The students in the school project 'Build your own future' created different stories (figure 1) about what the future might be like. They based their future scenarios partly on what they identified as changes in society before and today; however, to a great extent, they also integrated their own fantasies and wishes. The futures could describe societies in which we have solved the problems we currently face by changing our consumption patterns and policies; however, they could also describe worlds in which we have not solved our problems and their consequences have been played out. In the interviews, the students reacted to this variety of future versions: 'It made me think of how the world is today and how it can be, and the differences of how it can be in the future' (Student I). Two other students also voiced how the project gave them freedom to speculate. One commented: '2043-there is a lot of ways to imagine it. That's something I have learned. We can imagine it being really good or really bad' (student D). Another commented:

What I liked about the project is that there was no right or wrong. That we could see the year 2043. You could see it the way you wanted it. That there was nothing wrong with that. Some had it worse, and some made it better, and that was a good thing. (student F)

These student reflections of multiple stories and future possibilities indicate, in our view, insight into the complexity of reality and reflections regarding the multiple perspectives needed to understand reality.

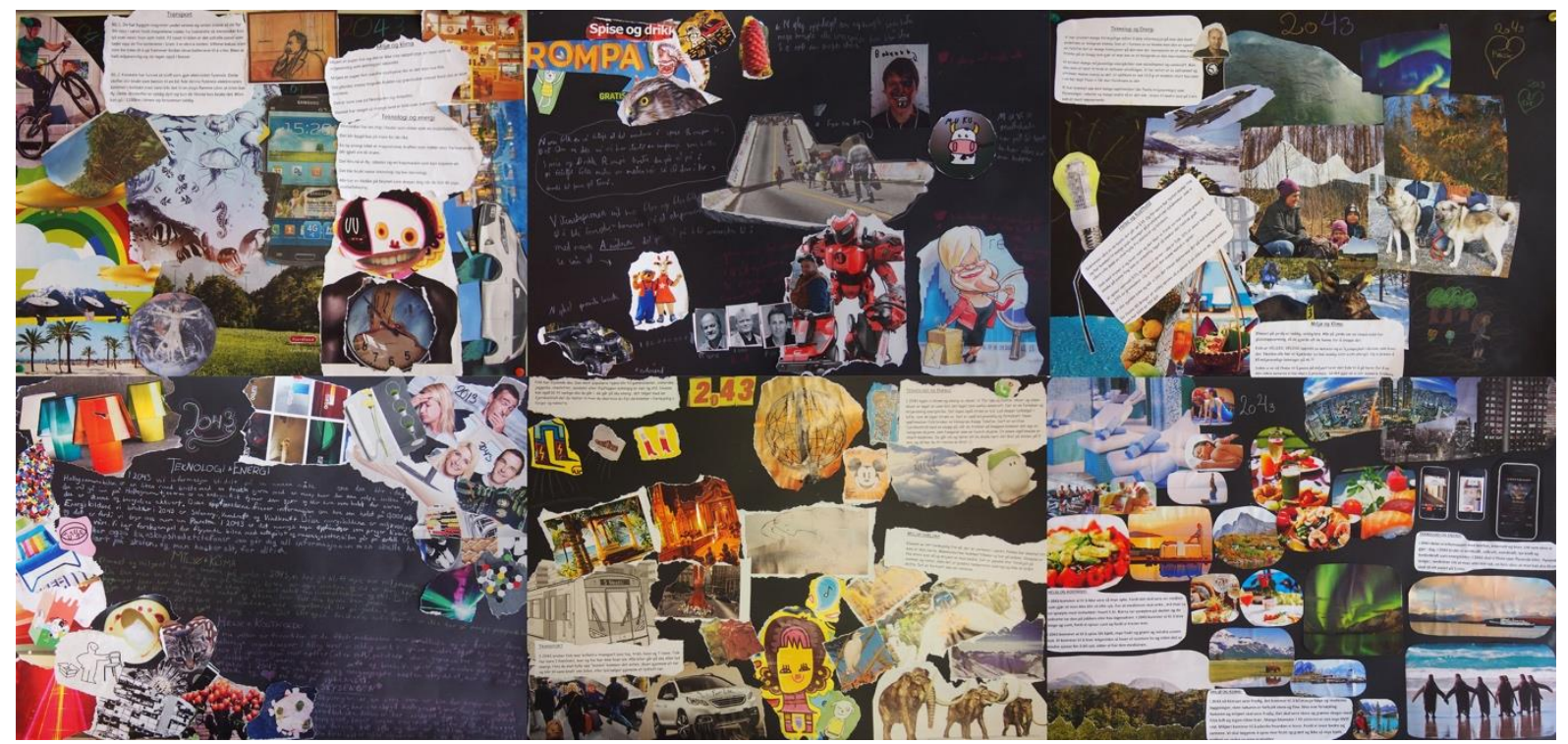

FIGURE 1: Six different future scenarios. Student collage presentations.

\section{The interdisciplinarity of future scenario-building}

We see the process of future scenario-building as interdisciplinary in that it is an activity characterised by 'integrating, interacting, linking, focusing and blending' (Klein, 2010). As part of the school project 'Build your own future', the students identified and described driving forces in the world's complexity. Lawrence Wilkinson (2009) described such driving forces as things that move the future in a specific direction, the identification of which can help us make better decisions. Driving forces can be understood as external and internal. Internal driving forces include knowledge and attitudes, while external driving forces can be technological, economic or natural (e.g. globalisation, the increasing greenhouse effect or increased life expectancy).

By identifying driving forces and describing changes that have happened and are happening, the students completed a set of research activities. The first task was to interview an elder and compare 
present society with society in the year 1983 (figure 2). The questions involved patterns of consumption and issues related to energy, technology, media, waste, transport, health and nutrition. The next task was researching these areas in groups, using web resources and statistics. The class then discussed what they had found out and what consequences their findings might have for future societies. In the variety of this work, the students gained different information about and perspectives on the driving forces described, including the variety of scientific fields, personal experience, society changing over time, global statistical information and group reflections. Through the subsequent scenario development, using visual communication and design thinking and methods, the students showed insight into the challenges we face today and tomorrow. Teaching situations that involve future scenario-building give students opportunities to see products in a larger context, which might facilitate a better understanding of such topics as consumption and environmental impact. In the words of one student: 'I didn't think much about it [...] Now that I get all this down on paper, I think it's much more important than that' (Student F). We question whether this approach can provide the students an opportunity to see challenges and problems within a holistic context and whether it can prevent the alienation of such issues as sustainability.
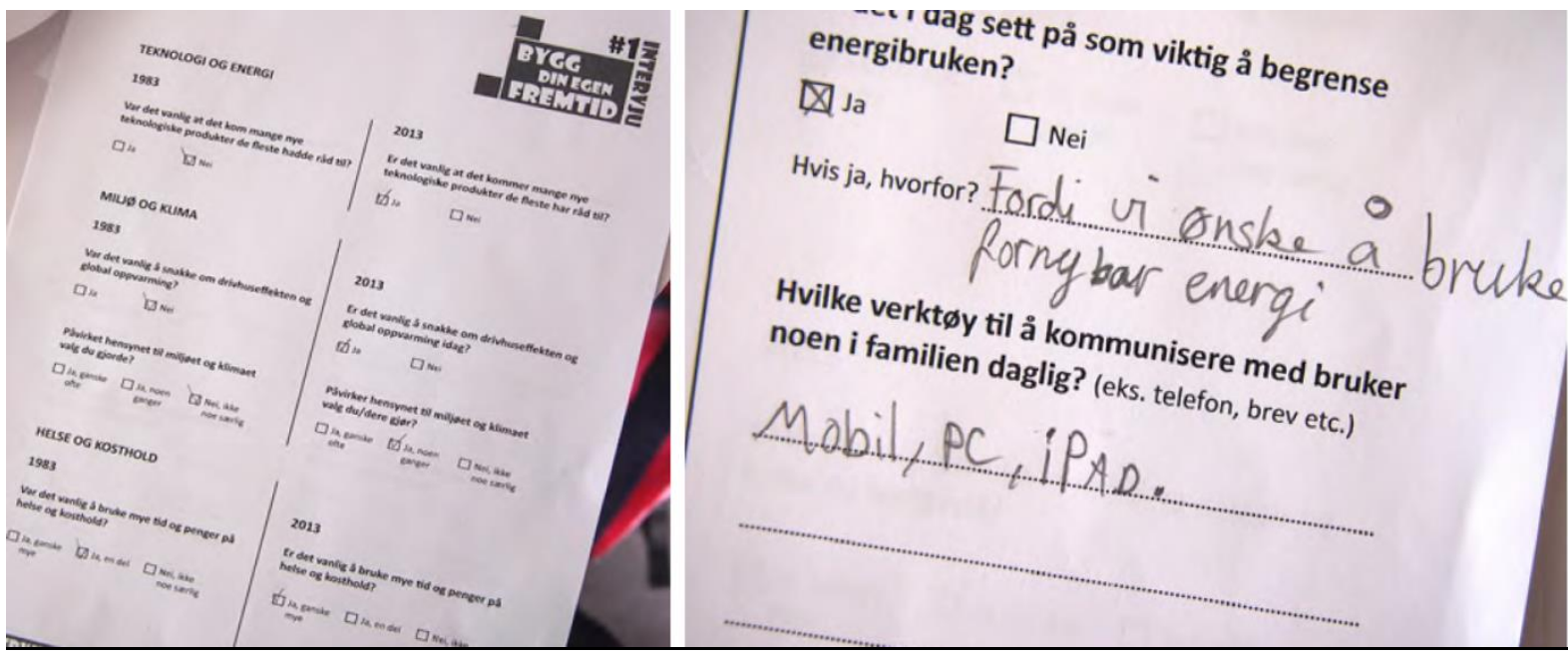

FIGURE 2: Student work from interviewing an elder.

\section{Design education contributing to reflective and critical thinking}

Future scenario-building and design seems to offer the possibility to be an interdisciplinary framework in general education for insight, reflection and critique. The stories provided by the students can engage the students themselves, fellow students and a wider public. It can provide a basis for discussions and reflections concerning ethics, societal and technological developments.

Richard Paul (1993) saw creative and critical thinking as similar. He defined critical thinking as follows:

Critical thinking is the intellectually disciplined process of actively and skillfully conceptualizing, applying, analyzing, synthesizing, and/or evaluating information gathered from, or generated by, observation, experience, reflection, reasoning, or communication, as a guide to belief and action. (Paul, 1993 p. 22)

In light of Paul's (1993) definition, we see the students' project work as an exercise in critical thinking. The students gathered and evaluated information, then analysed and applied the information in their stories and designs, thereby synthesizing it. They accomplished this through reflection, reasoning, communication and conceptualizing.

Early awareness and knowledge of societal challenges might make students more capable citizens in the future. Habits and consumption patterns cannot be changed overnight, and reflection and critique in general education may be key factors in successfully shifting current paradigms. Liv 
Merete Nielsen and Karen Brænne (2013) argued for design literacy as an important competence for citizens that promotes an understanding of materiality that encourages longer-lasting products and sustainable consumer choices. Stefano Marzano (2005) pointed to studies in brain research showing how consumers are influenced by thoughts of possible futures. We ask whether the insight the students acquired might be considered 'priming memories': an awareness that helps one be observant when meeting the challenges of everyday life and might influence their actions towards making more ethical choices.

Buch-Hansen and Nielsen (2005) have argued that actors do not exist in a structural vacuum, but, rather, can influence and be influenced by the structures around them. Social interaction and collaboration are necessary to change existing structures. One of the aims of education is to give students the tools to interact and collaborate to change existing structures to new ones and mould the future into a more sustainable one. Future scenarios can provide knowledge and serve as interdisciplinary arenas for interaction, collaboration, discussions and reflective thought. As such, they can foster more reflective attitudes towards future actions.

Working with the school project, the students reflected on their learning outcomes. Considering what might be and speculating in their school work was new to some students: 'I have never thought of how it will be in the year 2043. I haven't thought that far ahead before, so I have learned a lot about that and how it can be and such' (student G). In their discussions about the project, it became clear that the students' various stories, dark futures and possible outcomes triggered a diversity of reactions among fellow students: 'I don't hope [student name's] version comes true. That's the least I want' (student H). Other students commented: 'He wanted a third world war' (student G) and 'that cockroaches took over the world' (student $\mathrm{H}$ ). This dialogue and interchange of reflective thought can be compared to the contributions of speculative design with a focus on more negative and darker futures, according to Dunne and Raby (2013). Specifically, the students' future scenario and speculative design work sparked reactions, thoughts and reflections among their fellow students. Future stories that are negative and scary can help confirm what is positive and what kind of future society students want.

Design processes, tools and ways of thinking can equip youth to 'think outside the box'. However, to accomplish this objective, the students' tasks cannot be fixed or final in form. When the questions youth tackle within these problems are not right or wrong, but deal more with the ethical questions of good or bad solutions or consequences, reflective thoughts will drive the discussions, peer responses and consideration of societal driving forces, while considering how something can be 'good' but have 'bad' overall consequences for the environment or people.

The knowledge formed on basis of the data gathered, experiences and reflections from the school project 'Build your own future' has contributed to transforming the first author's teaching practice. McNiff (2013) emphasized the importance of using action research for transformation, using the knowledge you have earned through action research improving your practice. The first author has in recent teacher practice used the methods of future scenario-building in a wider educational context outside core design subjects. In the school projects 'Media 2046' and 'Media 2047', two newer projects within the Norwegian upper secondary educational programme Media and Communication, students identified media trends of today and tomorrow and created future scenarios through future scenariobuilding (Ringvold 2019). In this new project the students developed and produced media products and stories that took place within the future scenarios. The stories gave insight into a series of thoughts and reflections about the direction in which our society might move. The projects seemed to provide a framework for critical thinking and reflection. In Figure 3, a student tells a story about a future in which technological developments, robots and automated processes might threaten humanity. In Figure 4, a short film named twentyfour/seven, a student tells of a future in which constant pressure causes stress and unhappiness. 

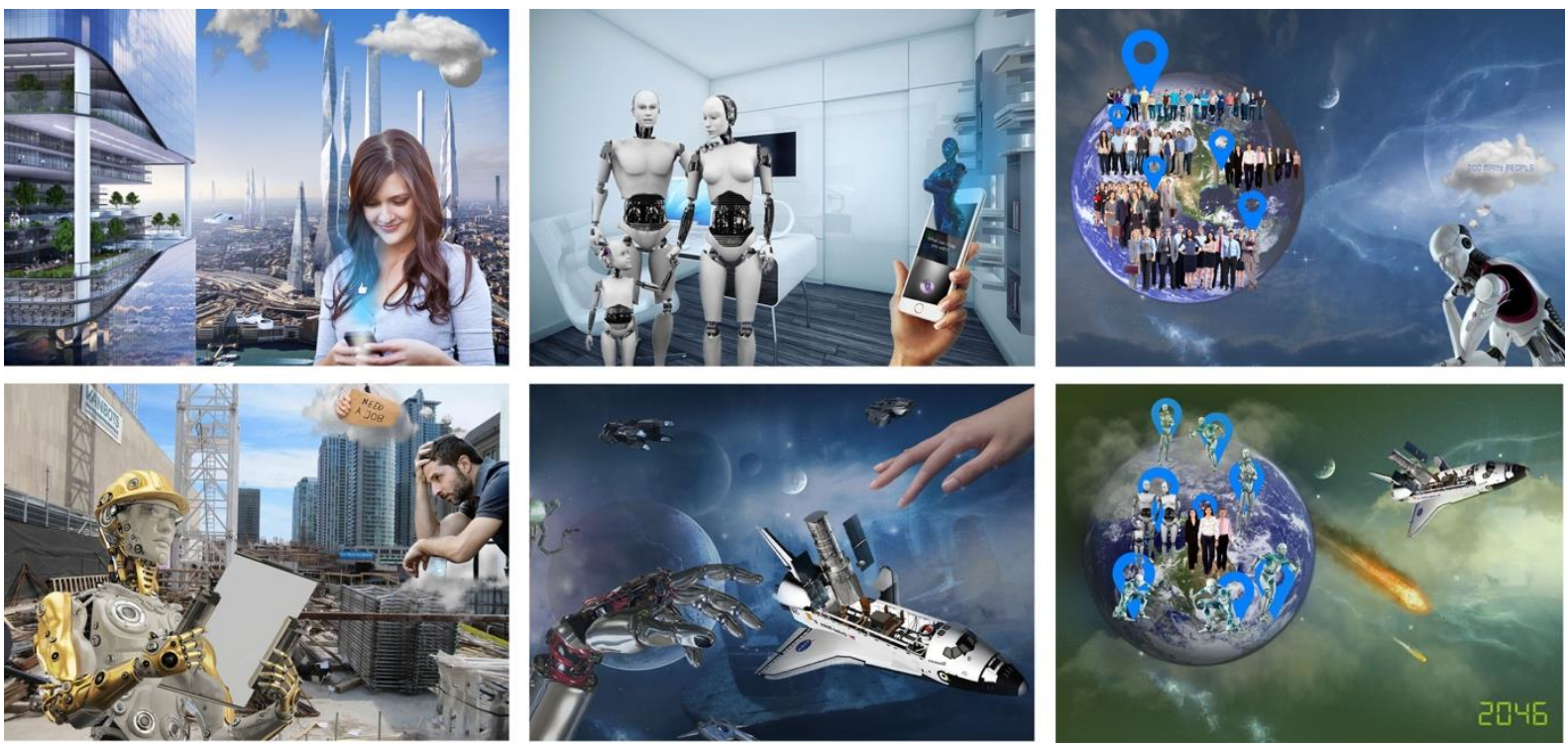

FIGURE 3. Media and communication. School project Media 2046. Student project work.
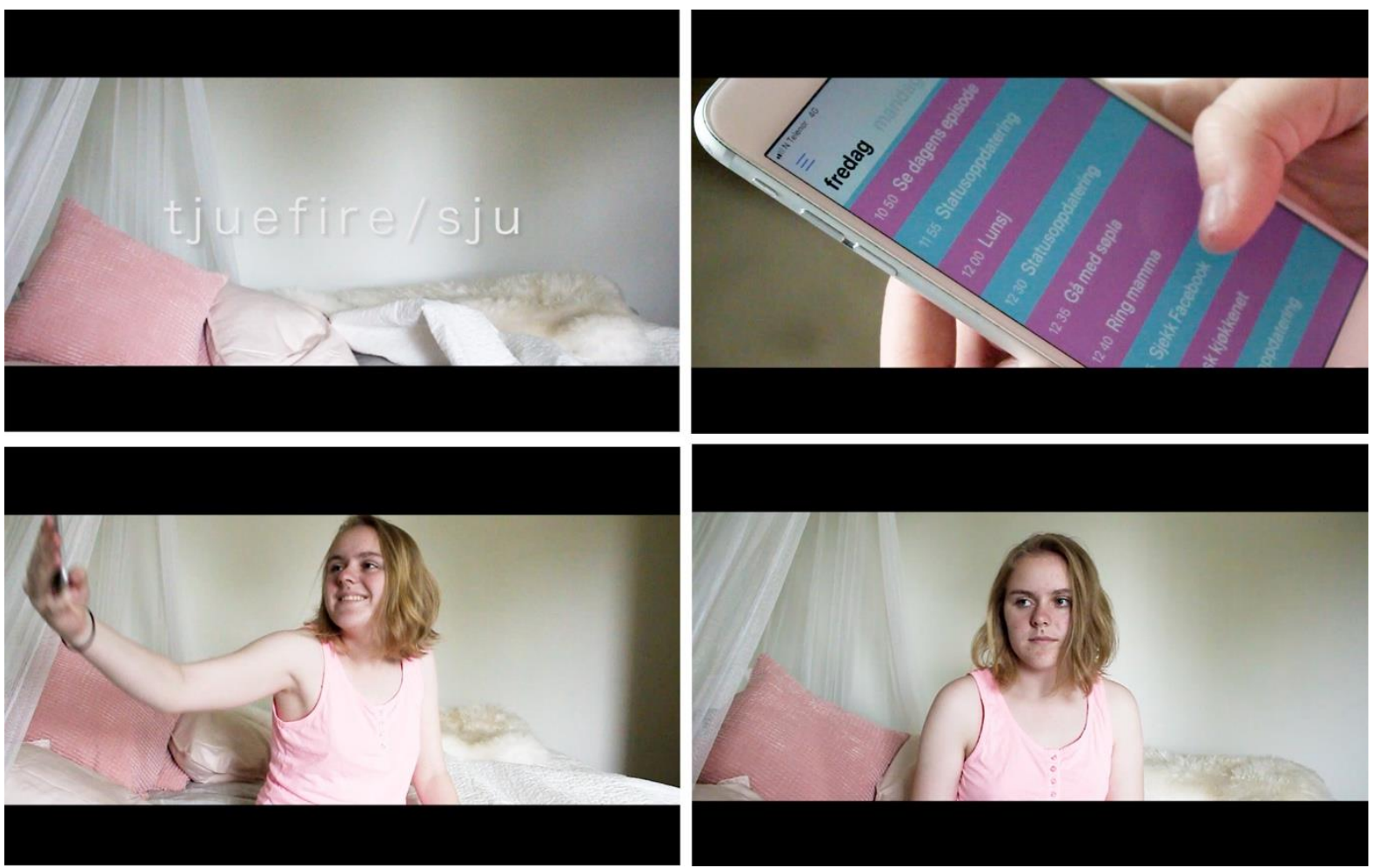

FIGURE 4. Media and communication. School project Media 2047. Student project work.

\section{Interdisciplinarity, design, creativity and innovation}

Interdisciplinary research can discover opportunities that require integrated and collaborative perspectives. Interdisciplinary design thinking can contribute to understanding the complexity or wickedness (Boradkar, 2010) of the problems we face. As Boradkar (2010) argues, '[t]he sheer wickedness and complexity of these issues warrants engagement with other disciplines' (p. 274).

Willis (2005) compared future scenario-building with design, as both are pre-figurative thought exercises. The students' work revealed how this pre-figurative thought process encouraged them to seek new solutions and give shape to something as yet unknown. This ability is seen as a fundamental 
human capacity and the basis for all design, not just professional design practice (Willis, 2005). Through general design education, this important capacity can be fostered in future generations and can contribute to the development of innovative skills not only among future professional designers, but among all future citizens.

In reflecting on their work with future scenarios, many of the students described a joy of shaping the unknown. They identified problems and described new solutions (Ringvold, 2014). Nigel Cross (2011) argued that good designers have a special way of thinking: 'Rather than solving merely "the problem as given" they apply their intelligence to the wider context and suggest imaginative apposite solutions that resolve conflicts and uncertainties' (p. 136). This description of design thinking is comparable to the students' project work. In their descriptions of the future, they identified problems of today and tomorrow, which they sought to solve with their design solutions. For example, one student designed a Cloud Bed (Figure 5), which is not only a hovering bed shaped as a cloud, but also part of photosynthesis. This problem-solving product emerged from the interdisciplinary research phase. The student work shows how interdisciplinarity in general design education can contribute to creative problem-solving. The use of future scenarios and speculative design can help develop human creativity and innovation. Through learning to see the bigger picture and products in a wider interdisciplinary context, students can develop problem-solving skills that support their research capabilities and creativity.
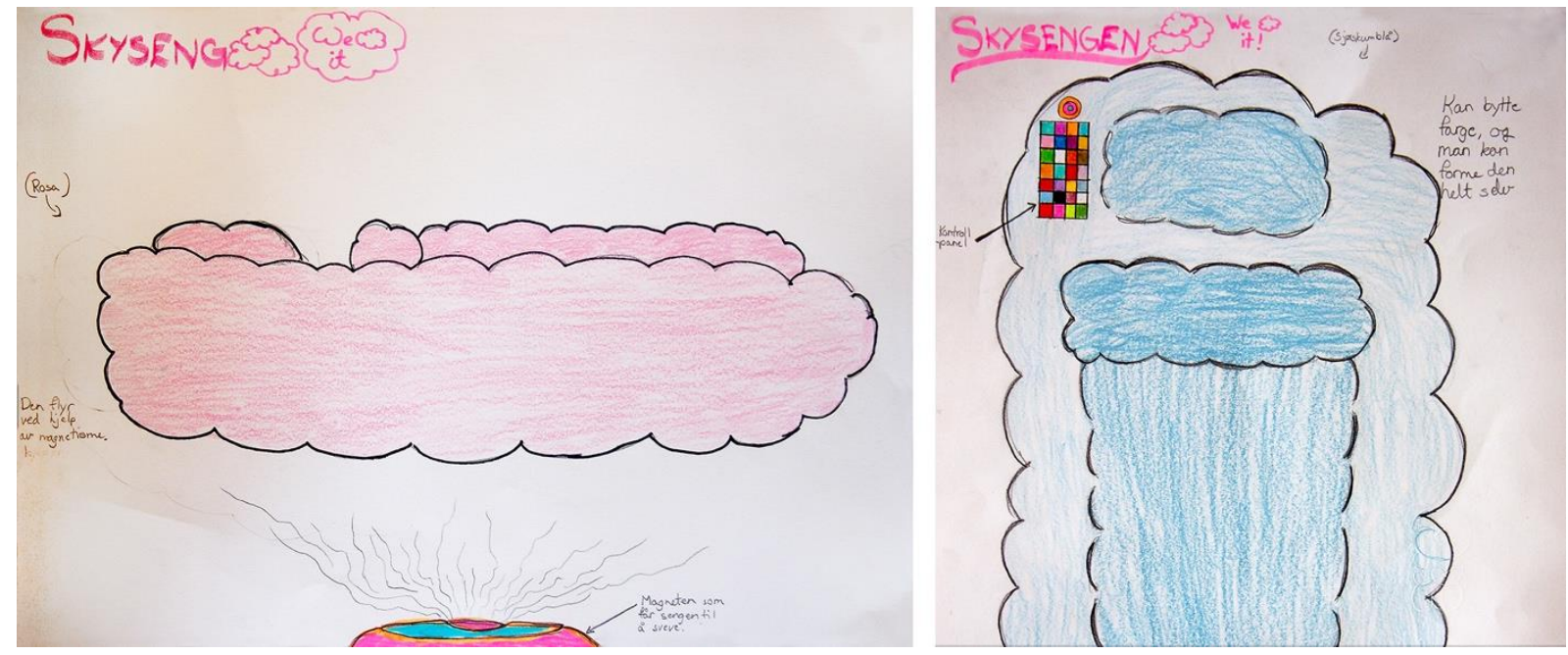

FIGURE 5. 7th grade student project work: Skyseng (English translation: Cloud Bed).

\section{Obstacles, limitations and challenges}

A school project like the one in this study has limitations, and its success is dependent on a series of factors identified during the study. As teaching in schools is not organized in an interdisciplinary manner, but organized in separate subjects, projects like this can be complicated to facilitate and manage. This project was dependent on the goodwill of the school management and teachers. The success of future projects is dependent on general design educators with insight into methods and processes. Ringvold organized and managed this project. Fully understanding the processes and purposes of all the tasks included in the project was considered important to engage the students and tutor them through the different stages and learning processes.

The project success was dependent on providing time for the tasks that needed to be done. In a school day with a tight schedule and minimal available time, projects that are time-consuming might be difficult to organize. On the other hand, by integrating a large set of skills and different subject benchmarks in the same project, an interdisciplinary approach like this can save time by accomplish learning for different subjects within one wider setting. 


\section{SUMMING UP}

Future scenario-building as part of a design school project can work as an interdisciplinary learning process and framework allowing for perspectives and insights that can contribute to students' ability to better see consequences and grasp the complexity of problems. Through seeing possible futures, be they negative or positive, students can gather and reflect on research and information in a wider context. By playing out the consequences of qualities, trends and changes in today's society, the students raised issues of ethical dilemmas concerning technology and sustainability. This gave them a platform for critical thinking.

The interdisciplinarity of design thinking and general design education projects fosters design literacy including the ability to experience complexity and understand complex problems in a wider context. A design literacy inclusive of design learning can enable students to better understand and reflect upon the challenges of an increasingly complex and rapidly changing society. This kind of design literacy and education for the general public can, in turn, promote sustainable decision-making and critical innovation. The results of these projects are however not generalizable. Time and space influence the outcome. Identifying phenomena and problem-solving through design processes, tools and ways of thinking can be a good interdisciplinarian framework for education because of the nature of the task. To better understand user needs, materials and the environmental consequences of product manufacturing and use, several different disciplines are needed. In light of this, we ask whether general design education can be a natural hub for interdisciplinary education for the general public. 


\section{REFERENCES}

Barnett, R. (2012). Learning for an unknown future. Higher Education Research \& Development, 31(3), 65-77. https://doi.org/10.1080/07294360.2012.642841

Boradkar, P. (2010). Design as problem solving. In R. Frodeman (Ed.), The Oxford handbook of interdisciplinarity (pp. 273-287). Oxford University Press.

Buch-Hansen, H., \& Nielsen, P. (2005). Kritisk realisme [Critical Realism]. Roskilde Universitetsforlag.

Capper, M. (2004). Scenarios as a design and product planning tool. Innovation, (Summer), 34-39.

Cross, N. (2011). Design thinking. Berg. https://doi.org/10.5040/9781474293884

Derbellay, F., Moody, Z., \& Lubart T. (2017). Creativity, design thinking and interdisciplinarity. Springer. https://doi.org/10.1007/978-981-10-7524-7

Dunne, A., \& Raby, F. (2013). Speculative everything: Design, fiction, and social dreaming. MIT Press.

Fuad-Luke, A. (2009). Design activism. Beautiful strangeness for a sustainable world. Earthscan.

Klein, J. T. (2010). A taxonomy of interdisciplinarity. In R. Frodeman (Ed.), The Oxford handbook of interdisciplinarity (pp. 15-30). Oxford University Press.

Malpass, M. (2017). Critical design in context. History, theory, and practices. Bloomsbury. https://doi.org/10.5040/9781474293822

Marzano, S. (2005). Past tense, future sense. Competing through creativity: 80 years of design at Philips. BIS Publishers.

McNiff, J. (2013). Action research. Principles and practice (3rd ed.). Routledge. https://doi.org/10.4324/9780203112755

Nielsen, L. M. (2013). Visualising ideas: A camera is not enough. In J. B. Reitan, P. Lloyd, E. Bohemia, L. M. Nielsen, I. Digranes, \& E. Lutnæs (Eds.), Design learning for tomorrow. Design education from kindergarten to PhD. Proceedings of the 2nd International Conference for Design Education Researchers. 14-17 May 2013, Oslo, Norway, (pp. 2080-2089). ABM media. https://hdl.handle.net/10642/1975

Nielsen, L.M. \& Brænne, K. (2013). Design literacy for longer-lasting products. Studies in material thinking, 9, 1-9. https://hdl.handle.net/10642/1871

Paul, R. W. (1993). The logic of creative and critical thinking. The American Behavioral Scientist, 37(1), 21-39. https://doi.org/10.1177/0002764293037001004

Ringvold, T. A. (2014) Bygg din egen fremtid. Fremtidsscenariobygging i faget kunst og håndverk [Build your own future. Future scenario building in the Norwegian school subject of Art and Crafts. Educational possibilities and civic ethical perspectives] (Master thesis, Høgskolen i Oslo og Akershus [Oslo and Akershus University College]). http://hdl.handle.net/10642/2114.

Ringvold, T.A. (2019) Scenariobygging, fremtidsfortellinger, kritisk tenkning og medieutvikling [Scenario building, future stories, critical thinking and media development]. Paper presented at the Network Conference for Norwegian design, art and craft education in higher education. University of South-East Norway, Notodden, 21. - 22. january, 2019.

Science Education Resource Centre. (2017). Why teach with an interdisciplinary approach. htttps://serc.carleton.edu/econ/interdisciplinary/why.html

Thorpe, A. (2007). The designer's atlas of sustainability. Island Press.

UNESCO. (1986). Interdisciplinarity in general education. A study by Louis d'Hainaut following an International Symposium on Interdisciplinarity in General Education held at UNESCO Headquarters from 1 to 5 July 1985. www.unesco.org/education/pdf/31_14.pdf

Willis, A. M. (2005). Editorial: Scenarios, futures and design. Design Philosophy Papers, 3(1), 1-7. https://doi.org/10.2752/144871305X13966254124077

Wilkinson, L. (2009). How to build scenarios. www.wired.com/wired/scenarios/build.html 
Tore Andre RINGVOLD \& Liv Merete NIELSEN - Complexity, interdisciplinarity and design literacy

${ }^{1}$ First published as Ringvold, Tore Andre \& Nielsen, Liv. (2019). Complexity, interdisciplinarity and design literacy. Conference Proceedings of the Academy for Design Innovation Management, 2(1). The article is republished with permission. 